ORIGINAL ARTICLE

\title{
Predicting mortality after kidney transplantation: a clinical tool
}

\author{
Sarbjit V. Jassal, ${ }^{1,2}$ Douglas E. Schaubel ${ }^{3}$ and Stanley S. A. Fenton ${ }^{1,2}$ \\ 1 Department of Medicine, University of Toronto, Toronto, Canada \\ 2 Division of Nephrology, University Health Network, Toronto, Canada \\ 3 Department of Biostatistics, School of Public Health, University of Michigan, Ann Arbor, MI, USA
}

\section{Keywords}

Charlson comorbidity index, comorbidity, outcome, patient survival, prognosis, renal transplant.

\section{Correspondence \\ Dr SV Jassal, Division of Nephrology, 200 Elizabeth St Room 8N-857, Toronto, ON, M5G 2C4 Canada. Tel.: +1 416340 3196; fax: +1 416340 4999; \\ e-mail vanita.jassal@uhn.on.ca}

Received: 27 June 2005

Revision requested: 14 July 2005

Accepted: 3 August 2005

doi:10.1111/j.1432-2277.2005.00212.x

\begin{abstract}
Summary
An increasing number of patients referred for transplantation are older and have complex comorbidity affecting outcome. Patient counseling is often empiric and time consuming. For the physician there are few clinical tools available to help quantify survival chances after transplantation. We used registry data to develop a series of tables that could be used in the clinical setting to predict survival probability. Using data from the Canadian Organ Replacement Registry, we generated clinical survival tables using Cox's regression model. Model covariates included age, race, gender, treatment period, primary renal disease cause, donor source, months on dialysis and comorbidities. A total of 6324 patients were included, $22 \%$ had $\geq 1$ comorbid condition at baseline. After adjustment for age, gender and cause of renal disease, increased comorbidity was strongly associated with reduced patient-survival $(P<0.05)$. Age and comorbidity specific clinical survival tables showing the expected 1-, 3- and 5 -year patient survival probabilities were generated. Separate tables were created for diabetics, nondiabetics, living-donor organs and deceased-donor transplantation. Patient-specific survival data can be estimated from registry data. We suggest annual or biannual tables generated by national registries across Europe and N. America, may be useful to those physicians faced with counseling patients and families.
\end{abstract}

\section{Introduction}

Across the world, nephrologists and epidemiologists are reporting dramatic changes in the demographics of the end-stage renal disease (ESRD) population [1-3]. Data show that patients are older, more likely to be diabetic and have an increased number of comorbid conditions. The trend to more aged, complex and frail patients is undoubtedly most dramatic in the dialysis population; however even within the pool of patients waiting for transplantation, the average age at the time of wait listing has increased over the last decade. For example, in our institution, the mean age at wait listing has risen from 45 to 52 years, with our oldest patient being over 80 years of age at the time of listing. Age is sometimes inappropri- ately used as a surrogate index of comorbidity; therefore, within the dialysis literature the use of age together with some index of comorbidity is advocated [4-7].

Multiple comorbidity indices have been developed for use in ESRD [8-11]. Few have been used in kidney transplantation. In fact, in a study by Gaylin et al. [12], individuals with comorbid conditions were found to be offered transplantation less frequently than those without any comorbidity. Using a cross-sectional design, Djukanovic et al. [13], showed comorbidity, as measured by the Index of Co-Existent disease (ICED) score, was closely associated with malnutrition but did not report patient outcome. As the demographics of the ESRD population change however, an increased proportion of patients with comorbid illnesses are being accepted as potential transplant recipients. In a 
recent study, the Charlson Comorbidity Index (CCI) [14] was found to be the most predictive of four comorbidity scores [7]. The objectives of the current project were to develop easy-to-use clinical survival tables, using the CCI score as a measure of comorbidity, for use in the office setting at the time of potential recipient evaluation.

\section{Methods}

\section{Data source}

Using administrative data from the Canadian Organ Replacement Registry (CORR) [3] all patients who started renal replacement therapy after 1988, and underwent renal transplantation during the period January 1, 1988 to December 31, 1998 were included in the study. Both demographic and clinical data were collected at the time of starting renal replacement therapy.

Canadian Organ Replacement Registry is a voluntary, countrywide registry, maintained by the Canadian Institute of Health Information. Data at registration includes demographic data (age, gender, race etc.); the primary diagnosis and details of comorbid conditions e.g. the presence or absence of angina, previous myocardial infarction, pulmonary edema, diabetes mellitus (including data about type 1 or type 2), previous cerebrovascular accidents, peripheral vascular disease, malignancy, chronic obstructive lung disease, hypertension or other serious illness (defined as 'a disease not falling into one of the previously listed categories which is expected to greatly reduce 5-year survival probability'). Follow-up data are recorded annually, and include data about changes in modality, death and causes of death. At the time of transplantation patients are re-registered. At this time additional data about the recipient serology, the donor serology and transplant donor characteristics are recorded. Data quality is maintained by ongoing cross-checking of data submitted in the different facility reports with capture of $93 \%$ of all dialysis patient data and $82 \%$ of all data for those with a functioning kidney transplant.

\section{Analytical methods and statistical analysis}

Cox regression was employed to model mortality using a previously validated model [7]. Survival was defined as

Table 1. Methods used to generate comorbidity score from administrative data.

\begin{tabular}{|c|c|c|c|}
\hline Comorbid conditions & $\begin{array}{l}\text { CORR database entry, and comments } \\
\text { about interpretation }\end{array}$ & $\begin{array}{l}\mathrm{CCl} \text { score } \\
\text { (original) }\end{array}$ & $\begin{array}{l}\mathrm{CCl} \text { scoring } \\
\text { used }\end{array}$ \\
\hline Angina & $\mathrm{Y} / \mathrm{N}$ & 0 & 0 \\
\hline Previous myocardial infarct & $\mathrm{Y} / \mathrm{N}$ & 1 & 1 \\
\hline Coronary artery bypass surgery & $\mathrm{Y} / \mathrm{N}$ & 0 & 0 \\
\hline Pulmonary edema/congestive cardiac failure & $\mathrm{Y} / \mathrm{N}$ & 1 & 1 \\
\hline Diabetes or diabetes with end organ disease & $\begin{array}{l}\text { Y/N - with details if type } 1 \text { or } 2 \text { only; } \\
\text { assumed to be diabetes with end organ disease }\end{array}$ & $\begin{array}{l}1 \\
2\end{array}$ & $2^{*}$ \\
\hline $\begin{array}{l}\text { Cerebrovascular accident with residual deficit or } \\
\text { without residual deficit }\end{array}$ & $\begin{array}{l}\text { Y/N - no details of deficit recorded } \\
\text { therefore assumed to have deficit }\end{array}$ & $\begin{array}{l}2 \\
1\end{array}$ & $2^{*}$ \\
\hline Peripheral vascular disease & $\mathrm{Y} / \mathrm{N}$ & 1 & 1 \\
\hline Dementia & Not recorded & 1 & $(1) \dagger$ \\
\hline Chronic obstructive lung disease (COLD) & $\mathrm{Y} / \mathrm{N}$ & 1 & 1 \\
\hline Connective tissue disease & $\begin{array}{l}\text { Recorded under other serious illness and/ } \\
\text { or as primary renal etiology }\end{array}$ & 1 & 1 \\
\hline Ulcer disease & Not recorded in registry & 1 & (1) \\
\hline Mild liver disease & Recorded under other serious illness & 1 & 1 \\
\hline Moderate or severe renal disease & Assumed to be present in all patients & 2 & 2 \\
\hline Any tumor or & & 2 & \\
\hline $\begin{array}{l}\text { Leukemia or Lymphoma or } \\
\text { Metastatic solid tumor }\end{array}$ & Only recorded as malignancy $\mathrm{Y} / \mathrm{N}$ & $\begin{array}{l}2 \\
6+\end{array}$ & $2 \dagger$ \\
\hline Moderate or severe liver disease & Recorded under other serious illness & 3 & $3 \dagger$ \\
\hline AIDS & Recorded under other serious illness & 6 & 6 \\
\hline Other serious disease & Y/N with text description & N/A & $\mathrm{N} / \mathrm{A}$ \\
\hline
\end{tabular}

Key to scoring table.

$\mathrm{Y} / \mathrm{N}$, comorbid condition is recorded as a unique variable as being present or absent.

Numbers in parentheses denotes the score that is appropriate for the comorbid condition, however data about the presence or absence was not available on the registry database.

*A higher score was assumed for all patients as detailed information was not available through the registry.

$\dagger$ Comorbid conditions felt to be unlikely in transplant candidates. 
the time from the date of transplantation to patient death or study end-date. Patients were followed beyond the date of graft failure if graft failure occurred and the patients returned to dialysis. Baseline covariates introduced into the model included age, gender, race, calendar period (divided into 1988-1990, 1991-1994 and 1995-1998), primary renal diagnosis, donor source (deceased versus living donor organs), and dialysis vintage. Dialysis vintage was defined as the time spent on dialysis prior to transplant surgery. The Cox models were stratified by age, to permit distinct age-group-specific baseline hazards which were not required to be proportional.

For each individual, their comorbidity was scored using the CCI score (Table 1). The CCI score was introduced into a regression model containing the adjustment covariates age, gender, race, calendar period (divided into 1988-1994 and 1995-1998), primary renal diagnosis, donor source (deceased versus living donor organs), dialysis vintage and comorbidity index. Survival probabilities were calculated for patients in 5-year age bands, for those with and without diabetes and for those receiving living donor and deceased donor organs.

\section{Results}

Patient and comorbidity characteristics

A total of 7180 patients underwent kidney transplantation over the 11 year time period spanning 1988-1998. Of these, 856 patients had no comorbidity data entered. These records were therefore excluded (Table 2). Twenty-three

Table 2. Demographic details of patients included and excluded in study.

\begin{tabular}{lll}
\hline & $\begin{array}{l}\text { Patients included } \\
n=6324\end{array}$ & $\begin{array}{l}\text { Patients excluded } \\
n=856\end{array}$ \\
\hline Age in years: mean (SD) & $42.2(14.9)$ & $39.3(16.0)$ \\
Male gender (\%) & 63.9 & 63.3 \\
Race (\%) & & \\
Caucasian & 80.3 & 63.7 \\
Black & 2.6 & 1.0 \\
Asian & 5.1 & 2.9 \\
Other & 12.0 & 32.4 \\
Time period (\%) & & \\
1988-1989 & 8.3 & 13.0 \\
1990-1994 & 45.6 & 60.1 \\
1995-1998 & 46.2 & 26.9 \\
Etiology of renal disease (\%) & & \\
Diabetes & 17.7 & 11.6 \\
Primary GN & 22.8 & 19.0 \\
PCKD & 10.8 & 7.7 \\
Vascular disease & 7.0 & 6.2 \\
Other & 41.8 & 55.5 \\
\hline
\end{tabular}

GN, glomerulonephritis; PCKD, polycystic kidney disease. percent of patients were transplanted using an organ from a living donor. In keeping with the Canadian population, the majority of patients were Caucasian with only $20 \%$ being from other ethnic backgrounds. Sixty-four percent of patients were male, with the average age at the time of transplantation being 42 years. A total of 6324 patients were included in the analysis. A large proportion of patients (71\%) had no comorbid conditions at the time of registration. The mean Charlson score of the population was $2.9 \pm 1.7$ with a strong bimodal appearance [7]. Despite the high number of patients with no comorbidity, 1827 patients had at least one additional comorbidity. A total of 789 deaths and 1634 graft failures were observed. The calculated crude mortality and graft failure rates were 30.1 and 72.7 per 1000 patient-years (PY), respectively.

\section{Clinical survival tables}

A series of clinical survival tables illustrating patient survival rates were generated (Appendix). The tables show the 1,3 and 5 year expected patient survival rates for patients of different age bands and comorbidity profiles. Separate tables were generated for those with diabetes and for nondiabetic patients. Although small gender differences in older patients with high comorbidity scores were noted, patient survival rates were only in the order of $0.5-1 \%$ higher in women than in men. Separate clinical survival tables for men and women are therefore not presented.

\section{Discussion}

This paper is the first to generate clinical predictive tables for kidney transplant recipients based on age, comorbidity status and the kidney source. These are designed for use in the office by the clinician counseling the patient, and family, with regards to outcome after renal transplantation. These tables, unlike other published survival tables [15], offer individualized 1-, 3- and 5-year patient survival rates, which simultaneously incorporate the cause of renal disease, patient age and amount of comorbid illness.

The results are arguably based on a relatively small cohort of patients who underwent transplantation in Canada during the period 1988 to 1998 , however as the survival rates quoted are similar to today, we believe the tables to still be of clinical value. One limitation is that $12 \%$ of patients initially identified, as having had a transplant did not have comorbidity data entered and were therefore excluded. These patients had similar baseline demographic features to those patients included in the study. We deliberately chose not to include donor transplant details (e.g. cold ischemia time, cross match details) in our analysis as we have derived clinical survival tables to be most useful in 
the pretransplant clinic setting. We acknowledge donor factors do influence long-term graft function and mortality [16]. As with all administrative datasets we are limited by the availability of the data. Our data are limited to Canadian patients, are dependent on the accuracy of the registry data and are limited to data spanning the 10 -year period 1988 to 1998 . We however believe this bias to be minimal.

The use of registry data to help with individualized patient counseling is appealing on many counts, particularly in the current age of on line data entry and data access. Such tables are long overdue, and can help individual clinicians in their clinical practice. Furthermore the quantification of survival probability for patients and families may promote living donation in those where there is still some hesitation. Finally one could also hypothesize that the accuracy of registry data will improve as clinicians become increasingly involved with the interpretation and results, and recognize the importance of accurate reporting.

In summary we propose that these clinical survival tables be used in the clinical setting to help counsel patients and families about kidney transplantation. If widely adopted, there may be a role for annual or biannual updates of similar tables, generated by regional or national registries. Furthermore, with current improvements in technology, in time one may predict that such tables could be updated real time, as data is received by the central database or registry.

\section{Acknowledgements}

These results were presented in part at the World Congress of Nephrology, the American Transplant Congress and the Canadian Society of Nephrology meetings in 2003. The collection and the maintenance of CORR data are made possible only by the collaboration of the 87 renal programs across Canada. The contribution of the current and past full-time staff assigned to the register at the Canadian Institute of Health Information (formerly the Hospital Medical Records Institute) has also been essential to the success of the register. The Canadian Society of Nephrology, the Canadian Society of Transplantation, the Canadian Association of Nephrology Nurses and Technologists and their constituent members, have also made an essential contribution to the register since its inception in 1981. CORR is wholly supported by grants from the Federal, Provincial and Territorial Ministries of Health through the Canadian Institute of Health Information budget. This study was funded by the Geoffrey H Wood Foundation.

\section{References}

1. Berthoux F, Jones E, Gellert R, Mendel S, Saker L, Briggs D. Epidemiological data of treated end-stage renal failure in the European Union (EU) during the year 1995: report of the European Renal Association Registry and the National Registries. Nephrol Dial Transplant 1999; 14: 2332.

2. National Institute of Diabetes and Digestive and Kidney Diseases. U.S. Renal Data Systems, Annual Data Report (on CD). Researchers Guide, Reference Tables and ADR Slides. Ann Arbor, M.I: United States Renal Data System Coordinating Center, 2001.

3. Canadian Institute for Health Information 2002. CORR Preliminary Report: Preliminary Statistics on Renal Failure and Solid Organ Transplantation in Canada. Ottawa, Ontario: Canadian Institute of Health Sciences, 2002.

4. Beddhu S, Bruns FJ, Saul M, Seddon P, Zeidel ML. A simple comorbidity scale predicts clinical outcomes and costs in dialysis patients. Am J Med 2000; 108: 609.

5. Eiam-Ong S, Sitprija V. Comorbidities in patients with end-stage renal disease in developing countries. Artif Organs 2002; 26: 753.

6. Khan IH, Catto GR, Edward N, Fleming LW, Henderson IS, MacLeod AM. Influence of coexisting disease on survival on renal-replacement therapy. Lancet 1993; 341: 415.

7. Jassal SV, Schaubel DE, Fenton SSA. Baseline comorbidity in kidney transplant recipients: a comparison of comorbidity indices. Am J Kidney Dis 2005; 46: 136.

8. Hemmelgarn BR, Manns BJ, Quan H, Ghali WA. Adapting the Charlson comorbidity index for use in patients with ESRD. Am J Kidney Dis 2003; 42: 125.

9. Miskulin DC, Athienites NV, Yan G, et al. Comorbidity assessment using the Index of Coexistent Diseases in a multicenter clinical trial. Kidney Int 2001; 60: 1498.

10. Van Manen JG, Korevaar JC, Dekker FW, Boeschoten EW, Bossuyt PM, Krediet RT. How to adjust for comorbidity in survival studies in ESRD patients: a comparison of different indices. Am J Kidney Dis 2002; 40: 82.

11. Van Manen JG, Korevaar JC, Dekker FW, Boeschoten EW, Bossuyt PM, Krediet RT. Adjustment for comorbidity in studies on health status in ESRD patients: which comorbidity index to use? J Am Soc Nephrol 2003; 14: 478.

12. Gaylin DS, Held PJ, Port FK, et al. The impact of comorbid and sociodemographic factors on access to renal transplantation. JAMA 1993; 269: 603.

13. Djukanovic L, Lezaic V, Blagojevic R, et al. Co-morbidity and kidney graft failure - two main causes of malnutrition in kidney transplant patients. Nephrol Dial Transplant 2003; 18: 68v.

14. Charlson ME, Pompei P, Ales KL, MacKenzie CR. A new method of classifying prognostic comorbidity in longitudinal studies: development and validation. J Chronic Dis 1987; 40: 373.

15. The organ procurement and transplantation network http://www.optn.org/data/annualReport.asp. 2004.

16. Loven C, Norden G, Nyberg G. Impact of cadaveric renal donor morbidity on long-term graft function. Transpl Int 2003; 16: 857. 


\section{Appendix}

\section{Clinical survival table}

The following tables use four determinants (age, diabetic status, comorbidity index score and the donor source) to predict kidney transplant patient outcome.

Each table is divided according to age and comorbidity score. To identify the patient survival for a patient aged 36 year with a Charlson comorbidity score of, for example 5, one would scan across the top of the section labeled patient survival, until the column labeled 'CCI Score 3-5', and down to the row labeled age 35-39 years. The data contained within this box includes the 1-, 3- and 5-year patient survival (and confidence intervals) specific to that patient.

Table 1 of (6)

\begin{tabular}{|c|c|c|c|c|}
\hline \multirow[b]{3}{*}{ Age (years) } & & \multicolumn{3}{|c|}{$\begin{array}{l}\text { Diabetic nephropathy } \\
\text { Living donor } \\
\text { Transplantation approximately } 6 \text { months after initiation of dialysis }\end{array}$} \\
\hline & & \multicolumn{3}{|c|}{$\begin{array}{l}\text { Patient survival } \\
\text { (Expressed as \% survival with confidence intervals in brackets) }\end{array}$} \\
\hline & & Charlson score 2 & Charlson score $3-5$ & Charlson score $\geq 6$ \\
\hline \multirow[t]{3}{*}{$15-24$} & 1 yr survival & $99.1(97.8-99.7)$ & $98.7(96.9-99.5)$ & 98.3 (95.9-99.3) \\
\hline & 3 yr survival & $98.1(96.2-99.0)$ & $97.3(94.7-98.6)$ & $96.4(92.9-98.2)$ \\
\hline & 5 yr survival & $96.5(93.8-98.1)$ & $95.0(91.4-97.2)$ & $93.5(88.6-96.3)$ \\
\hline \multirow[t]{3}{*}{$25-29$} & 1 yr survival & $98.6(97.2-99.2)$ & $97.9(96.1-99.0)$ & $97.3(94.8-98.6)$ \\
\hline & 3 yr survival & $98.1(96.4-98.9)$ & $97.3(95.1-98.5)$ & $96.4(93.5-98.0)$ \\
\hline & 5 yr survival & $96.1(93.3-97.7)$ & $94.4(90.9-96.6)$ & $92.6(87.9-95.5)$ \\
\hline \multirow[t]{3}{*}{$30-34$} & 1 yr survival & $98.7(97.6-99.3)$ & $98.1(96.7-98.9)$ & $97.5(95.6-98.6)$ \\
\hline & 3 yr survival & $97.7(96.1-98.6)$ & $96.7(94.7-97.9)$ & $95.6(92.9-97.3)$ \\
\hline & 5 yr survival & $96.3(94.2-97.7)$ & $94.8(92.1-96.6)$ & 93.1 (89.5-95.6) \\
\hline \multirow[t]{3}{*}{$35-39$} & 1 yr survival & $98.2(97.0-99.0)$ & $97.5(95.9-98.4)$ & 96.7 (94.5-97.9) \\
\hline & 3 yr survival & $96.1(94.0-97.5)$ & $94.5(91.8-96.2)$ & $92.7(89.2-95.1)$ \\
\hline & 5 yr survival & $93.6(90.3-95.8)$ & 90.8 (86.9-93.6) & $88.0(82.9-91.7)$ \\
\hline \multirow[t]{3}{*}{$40-44$} & 1 yr survival & $98.0(96.7-98.8)$ & $97.1(95.5-98.2)$ & $96.2(94.0-97.6)$ \\
\hline & 3 yr survival & $96.3(94.3-97.6)$ & $94.7(92.3-96.4)$ & $93.1(89.8-95.3)$ \\
\hline & 5 yr survival & $93.1(89.6-95.4)$ & $90.2(86.0-93.1)$ & $87.1(81.8-91.0)$ \\
\hline \multirow[t]{3}{*}{$45-49$} & 1 yr survival & $97.9(96.5-98.7)$ & $97.0(95.2-98.1)$ & $96.0(93.6-97.5)$ \\
\hline & 3 yr survival & $96.1(94.0-97.6)$ & $94.5(91.8-96.3)$ & $92.7(89.1-95.1)$ \\
\hline & 5 yr survival & $93.6(90.2-95.8)$ & $90.9(86.8-93.8)$ & $88.1(82.7-91.8)$ \\
\hline \multirow[t]{3}{*}{$50-54$} & 1 yr survival & $96.3(94.3-97.7)$ & $94.8(92.2-96.5)$ & 93.1 (89.9-95.4) \\
\hline & 3 yr survival & $94.0(91.0-96.1)$ & $91.5(87.9-94.1)$ & $88.8(84.1-92.2)$ \\
\hline & 5 yr survival & $91.4(87.1-94.2)$ & $87.8(82.8-91.2)$ & $84.0(77.7-88.7)$ \\
\hline \multirow[t]{3}{*}{$55-59$} & 1 yr survival & $95.8(93.4-97.3)$ & $93.6(91.0-96.0)$ & $92.1(88.2-94.7)$ \\
\hline & 3 yr survival & $92.6(88.8-95.1)$ & $89.4(85.0-92.6)$ & $86.2(80.6-90.3)$ \\
\hline & 5 yr survival & $87.8(82.0-91.8)$ & $82.8(76.3-87.7)$ & $77.8(69.8-84.0)$ \\
\hline \multirow[t]{3}{*}{$60-64$} & 1 yr survival & $95.0(92.0-96.8)$ & $92.8(89.2-95.2)$ & $90.5(85.9-93.7)$ \\
\hline & 3 yr survival & $89.2(83.9-92.9)$ & $84.8(78.7-89.3)$ & $80.3(72.7-86.0)$ \\
\hline & 5 yr survival & $83.6(76.1-89.0)$ & $77.2(68.9-83.6)$ & $70.9(60.9-78.8)$ \\
\hline \multirow[t]{3}{*}{$65+$ years } & 1 yr survival & $94.9(91.6-96.9)$ & $92.7(88.6-95.4)$ & $90.4(85.2-93.9)$ \\
\hline & 3 yr survival & $90.2(84.9-93.8)$ & $86.2(79.9-90.7)$ & $82.1(74.2-87.8)$ \\
\hline & 5 yr survival & $84.7(76.8-90.0)$ & $78.6(69.7-85.2)$ & $72.6(61.8-80.7)$ \\
\hline
\end{tabular}


Table 2 of (6)

\begin{tabular}{|c|c|c|c|c|}
\hline \multirow[b]{3}{*}{ Age (years) } & & \multicolumn{3}{|c|}{$\begin{array}{l}\text { Nondiabetic nephropathy } \\
\text { Living donor } \\
\text { Transplantation approximately } 6 \text { months after initiation of dialysis }\end{array}$} \\
\hline & & \multicolumn{3}{|c|}{$\begin{array}{l}\text { Patient survival } \\
\text { (Expressed as \% survival with confidence intervals in brackets) }\end{array}$} \\
\hline & & Charlson score 2 & Charlson score 3-5 & Charlson score $\geq 6$ \\
\hline \multirow[t]{3}{*}{$15-24$} & 1 yr survival & $99.5(98.7-99.8)$ & $99.2(98.0-99.7)$ & 98.9 (97.3-99.6) \\
\hline & 3 yr survival & $98.8(97.7-99.4)$ & $98.3(96.6-99.1)$ & 97.7 (95.4-98.9) \\
\hline & 5 yr survival & $97.8(96.2-98.7)$ & $96.9(94.5-98.2)$ & $95.8(92.4-97.8)$ \\
\hline \multirow[t]{3}{*}{$25-29$} & 1 yr survival & $99.1(98.3-99.5)$ & $98.7(97.5-99.3)$ & $98.3(96.5-99.2)$ \\
\hline & 3 yr survival & $98.8(97.8-99.3)$ & $98.3(96.8-99.1)$ & 97.7 (95.7-98.8) \\
\hline & 5 yr survival & $97.5(96.0-98.5)$ & $96.4(94.1-97.9)$ & $95.3(91.8-97.3)$ \\
\hline \multirow[t]{3}{*}{$30-34$} & 1 yr survival & $99.2(98.5-99.5)$ & 98.8 (97.9-99.3) & $98.4(97.1-99.2)$ \\
\hline & 3 yr survival & $98.5(97.6-99.1)$ & $97.9(96.5-98.7)$ & $97.2(95.2-98.4)$ \\
\hline & 5 yr survival & $97.8(96.5-98.5)$ & $96.7(94.8-97.9)$ & $95.6(92.8-97.4)$ \\
\hline \multirow[t]{3}{*}{$35-39$} & 1 yr survival & $98.9(98.2-99.3)$ & $98.4(97.3-99.0)$ & $97.9(96.3-98.8)$ \\
\hline & 3 yr survival & $97.6(96.4-98.4)$ & $96.5(94.5-97.9)$ & $95.4(92.6-97.1)$ \\
\hline & 5 yr survival & $95.9(94.1-97.2)$ & $94.2(91.4-96.0)$ & $92.3(88.1-95.1)$ \\
\hline \multirow[t]{3}{*}{$40-44$} & 1 yr survival & $98.7(98.0-99.2)$ & $98.2(97.1-98.9)$ & $97.6(96.0-98.6)$ \\
\hline & 3 yr survival & $97.7(96.6-98.4)$ & $96.7(95.0-97.8)$ & 95.6 (93.1-97.2) \\
\hline & 5 yr survival & $95.6(93.7-96.9)$ & $93.7(90.9-95.7)$ & $91.7(87.4-94.6)$ \\
\hline \multirow[t]{3}{*}{$45-49$} & 1 yr survival & $98.7(97.9-99.2)$ & $98.1(96.9-98.8)$ & $97.5(95.7-98.5)$ \\
\hline & 3 yr survival & $97.6(96.4-98.4)$ & $96.5(94.7-97.7)$ & $95.4(92.6-97.1)$ \\
\hline & 5 yr survival & $95.9(94.1-97.2)$ & $94.2(91.3-96.1)$ & $92.3(88.1-95.1)$ \\
\hline \multirow[t]{3}{*}{$50-54$} & 1 yr survival & $97.7(96.6-98.4)$ & $96.7(95.0-97.8)$ & $95.6(93.1-97.2)$ \\
\hline & 3 yr survival & $96.2(94.6-97.6)$ & $94.6(92.1-96.3)$ & $92.8(89.1-95.3)$ \\
\hline & 5 yr survival & $94.5(92.2-96.1)$ & $92.1(88.7-94.5)$ & $89.7(84.4-93.2)$ \\
\hline \multirow[t]{3}{*}{$55-59$} & 1 yr survival & $97.3(96.0-98.2)$ & $96.2(94.2-97.4)$ & $94.9(92.0-96.8)$ \\
\hline & 3 yr survival & $95.3(93.3-96.7)$ & $93.2(90.2-95.3)$ & $91.1(86.6-94.1)$ \\
\hline & 5 yr survival & $92.2(89.0-94.4)$ & $88.9(84.3-92.2)$ & $85.5(78.6-90.2)$ \\
\hline \multirow[t]{3}{*}{$60-64$} & 1 yr survival & $96.8(95.2-97.9)$ & $95.4(93.1-97.0)$ & $93.9(90.5-96.2)$ \\
\hline & 3 yr survival & $93.1(90.3-95.1)$ & $90.2(86.0-93.1)$ & $87.1(80.9-91.4)$ \\
\hline & 5 yr survival & $89.4(85.3-92.4)$ & $85.0(79.1-89.4)$ & 80.6 (71.9-86.8) \\
\hline \multirow[t]{3}{*}{$65+$ years } & 1 yr survival & $96.8(95.0-97.9)$ & $95.4(92.7-97.1)$ & $93.9(90.0-96.3)$ \\
\hline & 3 yr survival & $93.8(90.9-95.8)$ & $91.1(86.9-94.0)$ & $88.3(82.2-92.5)$ \\
\hline & 5 yr survival & $90.1(85.7-93.2)$ & $86.0(79.7-90.4)$ & $81.8(72.8-88.0)$ \\
\hline
\end{tabular}




\begin{tabular}{|c|c|c|c|c|}
\hline \multirow[b]{3}{*}{ Age (years) } & & \multicolumn{3}{|c|}{$\begin{array}{l}\text { Diabetic } \\
\text { Deceased donor } \\
\text { Kidney transplantation } 24 \text { months after initiation of dialysis }\end{array}$} \\
\hline & & \multicolumn{3}{|c|}{$\begin{array}{l}\text { Patient survival } \\
\text { (Expressed as \% survival with confidence intervals in brackets) }\end{array}$} \\
\hline & & Charlson score 2 & Charlson score $3-5$ & Charlson score $\geq 6$ \\
\hline \multirow[t]{3}{*}{$15-24$} & $1 \mathrm{yr}$ survival & $98.4(96.1-99.4)$ & $97.8(94.6-99.1)$ & $97.0(92.8-98.8)$ \\
\hline & 3 yr survival & $96.6(93.4-98.3)$ & $95.1(90.8-97.5)$ & $93.6(87.9-96.7)$ \\
\hline & 5 yr survival & $93.9(89.3-96.5)$ & $91.2(85.2-94.9)$ & $88.5(80.8-93.3)$ \\
\hline \multirow[t]{3}{*}{$25-29$} & $1 \mathrm{yr}$ survival & $97.5(95.1-98.7)$ & $96.4(93.2-98.1)$ & $95.2(91.0-97.5)$ \\
\hline & 3 yr survival & $96.6(93.9-98.1)$ & $95.1(91.5-97.2)$ & $93.6(88.8-96.4)$ \\
\hline & 5 yr survival & $93.1(88.6-95.8)$ & $90.1(84.5-93.8)$ & $87.1(79.8-91.9)$ \\
\hline \multirow[t]{3}{*}{$30-34$} & 1 yr survival & $97.7(95.8-98.7)$ & $96.6(94.2-98.0)$ & $95.6(92.4-97.4)$ \\
\hline & 3 yr survival & $95.9(93.3-97.4)$ & $94.1(90.8-96.2)$ & $92.2(87.9-95.0)$ \\
\hline & 5 yr survival & $93.6(90.1-95.9)$ & $90.8(86.5-93.8)$ & $88.0(82.4-91.9)$ \\
\hline \multirow[t]{3}{*}{$35-39$} & 1 yr survival & $96.8(94.8-98.1)$ & $95.5(92.9-97.1)$ & $94.0(90.6-96.2)$ \\
\hline & 3 yr survival & $93.2(89.9-95.4)$ & $90.3(86.3-93.1)$ & $87.2(82.1-91.0)$ \\
\hline & 5 yr survival & $88.7(83.8-92.2)$ & $84.1(78.5-88.3)$ & $79.4(72.3-84.9)$ \\
\hline \multirow[t]{3}{*}{$40-44$} & $1 \mathrm{yr}$ survival & $96.4(94.3-97.8)$ & $94.9(92.3-96.6)$ & $93.2(89.9-95.5)$ \\
\hline & 3 yr survival & $93.5(90.4-95.6)$ & $90.7(87.1-93.4)$ & $87.9(83.2-91.3)$ \\
\hline & 5 yr survival & $87.9(82.8-91.6)$ & $83.0(77.3-87.3)$ & $78.0(70.9-83.5)$ \\
\hline \multirow[t]{3}{*}{$45-49$} & $1 \mathrm{yr}$ survival & $96.2(94.0-97.7)$ & $94.6(91.8-96.5)$ & $92.9(89.2-95.3)$ \\
\hline & 3 yr survival & $93.1(89.8-95.5)$ & $90.2(86.2-93.1)$ & $87.2(82.1-91.0)$ \\
\hline & 5 yr survival & $88.8(83.7-92.3)$ & $84.1(78.3-88.5)$ & $79.5(72.2-85.1)$ \\
\hline \multirow[t]{3}{*}{$50-54$} & $1 \mathrm{yr}$ survival & $93.5(90.4-95.7)$ & $90.8(87.1-93.4)$ & $87.9(83.2-91.4)$ \\
\hline & 3 yr survival & $89.5(85.1-92.7)$ & $85.2(80.3-89.0)$ & $80.8(74.6-85.6)$ \\
\hline & 5 yr survival & $85.0(79.0-89.4)$ & $79.0(72.6-84.1)$ & $73.1(65.2-79.5)$ \\
\hline \multirow[t]{3}{*}{$55-59$} & 1 yr survival & $92.5(88.8-95.1)$ & $89.4(85.1-92.5)$ & $86.1(80.7-90.1)$ \\
\hline & 3 yr survival & $87.0(81.5-91.0)$ & $81.7(75.8-86.4)$ & $76.5(69.2-82.2)$ \\
\hline & 5 yr survival & $79.1(71.1-85.1)$ & $71.2(63.0-77.9)$ & $63.6(54.2-71.6)$ \\
\hline \multirow[t]{3}{*}{$60-64$} & $1 \mathrm{yr}$ survival & $91.1(86.7-94.1)$ & $87.4(82.3-91.1)$ & $83.5(77.2-88.2)$ \\
\hline & 3 yr survival & $81.4(74.1-86.9)$ & $74.2(66.6-80.4)$ & $67.3(58.3-74.7)$ \\
\hline & 5 yr survival & $72.5(62.7-80.1)$ & $62.7(53.2-70.9)$ & $53.8(43.3-63.2)$ \\
\hline \multirow[t]{3}{*}{$65+$ years } & $1 \mathrm{yr}$ survival & $91.0(86.0-94.2)$ & $87.2(81.4-91.3)$ & $83.4(76.1-88.6)$ \\
\hline & 3 yr survival & $83.1(75.6-88.5)$ & $76.5(68.3-82.8)$ & $70.0(60.4-77.8)$ \\
\hline & 5 yr survival & $74.1(63.7-81.9)$ & $64.7(54.2-73.4)$ & $56.1(44.4-66.2)$ \\
\hline
\end{tabular}


Table 4 of (6)

\begin{tabular}{|c|c|c|c|c|}
\hline \multirow[b]{3}{*}{ Age (years) } & & \multicolumn{3}{|c|}{$\begin{array}{l}\text { Non-diabetic } \\
\text { Deceased donor } \\
\text { Kidney transplantation } 24 \text { months after initiation of dialysis }\end{array}$} \\
\hline & & \multicolumn{3}{|c|}{$\begin{array}{l}\text { Patient survival } \\
\text { (Expressed as \% survival with confidence intervals in brackets) }\end{array}$} \\
\hline & & Charlson score 2 & Charlson score $3-5$ & Charlson score $\geq 6$ \\
\hline \multirow[t]{3}{*}{$15-24$} & 1 yr survival & $99.0(97.6-99.6)$ & $98.6(96.5-99.4)$ & $98.1(95.3-99.2)$ \\
\hline & 3 yr survival & $97.9(96.0-98.9)$ & $96.9(94.1-98.4)$ & $95.9(92.0-98.0)$ \\
\hline & 5 yr survival & $96.1(93.5-97.7)$ & $94.4(90.5-96.7)$ & $92.6(87.0-95.9)$ \\
\hline \multirow[t]{3}{*}{$25-29$} & 1 yr survival & $98.4(97.0-99.2)$ & $97.7(95.6-98.8)$ & $97.0(94.0-98.5)$ \\
\hline & 3 yr survival & $97.9(96.2-98.8)$ & $96.9(94.5-98.2)$ & $95.9(92.5-97.8)$ \\
\hline & 5 yr survival & $95.6(93.0-97.2)$ & $93.7(89.8-96.1)$ & $91.7(86.1-95.1)$ \\
\hline \multirow[t]{3}{*}{$30-34$} & 1 yr survival & $98.5(97.5-99.1)$ & $97.9(96.2-98.8)$ & $97.2(94.9-98.4)$ \\
\hline & 3 yr survival & $97.4(95.9-98.3)$ & $96.2(94.0-97.6)$ & $95.0(91.8-97.0)$ \\
\hline & 5 yr survival & $95.9(94.0-97.2)$ & $94.1(91.1-96.1)$ & $92.3(87.9-95.1)$ \\
\hline \multirow[t]{3}{*}{$35-39$} & 1 yr survival & $98.0(96.9-98.7)$ & $97.1(95.4-98.2)$ & $96.2(93.7-97.7)$ \\
\hline & 3 yr survival & $95.6(93.8-96.9)$ & $93.8(91.0-95.7)$ & $91.8(87.6-94.6)$ \\
\hline & 5 yr survival & $92.8(90.1-94.7)$ & $89.7(85.6-92.6)$ & $86.5(80.3-90.9)$ \\
\hline \multirow[t]{3}{*}{$40-44$} & 1 yr survival & $97.8(96.6-98.5)$ & $96.7(95.0-97.9)$ & $95.7(93.1-97.3)$ \\
\hline & 3 yr survival & $95.9(94.2-97.1)$ & $94.1(91.6-95.8)$ & $92.2(88.3-94.8)$ \\
\hline & 5 yr survival & $92.2(89.5-94.2)$ & 88.9 (84.9-91.9) & $85.6(79.3-90.0)$ \\
\hline \multirow[t]{3}{*}{$45-49$} & 1 yr survival & $97.6(96.4-98.4)$ & $96.6(94.7-97.8)$ & $95.5(92.7-97.2)$ \\
\hline & 3 yr survival & 95.6 (93.9-96.9) & $93.8(91.1-95.7)$ & $91.8(87.7-94.6)$ \\
\hline & 5 yr survival & $92.8(90.1-94.8)$ & $89.7(85.7-92.7)$ & $86.6(80.4-90.9)$ \\
\hline \multirow[t]{3}{*}{$50-54$} & 1 yr survival & $95.9(94.3-97.1)$ & $94.1(91.7-95.8)$ & $92.2(88.4-94.8)$ \\
\hline & 3 yr survival & $93.3(91.1-95.0)$ & $90.4(87.0-93.0)$ & $87.5(82.1-91.3)$ \\
\hline & 5 yr survival & $90.3(87.2-92.6)$ & $86.2(81.7-89.8)$ & $82.1(75.0-87.4)$ \\
\hline \multirow[t]{3}{*}{$55-59$} & 1 yr survival & $95.2(93.3-96.6)$ & $93.2(90.4-95.2)$ & $91.0(86.7-94.0)$ \\
\hline & 3 yr survival & $91.6(88.8-93.7)$ & $88.1(84.0-91.2)$ & $84.5(78.2-89.1)$ \\
\hline & 5 yr survival & $86.3(82.2-89.5)$ & $80.8(74.9-85.5)$ & $75.3(66.4-82.2)$ \\
\hline \multirow[t]{3}{*}{$60-64$} & 1 yr survival & $94.3(92.0-95.9)$ & $91.9(88.5-94.3)$ & $89.3(84.3-92.8)$ \\
\hline & 3 yr survival & $87.9(84.2-90.8)$ & $82.9(77.6-87.1)$ & $78.0(69.8-84.2)$ \\
\hline & 5 yr survival & $81.7(76.6-85.8)$ & $74.6(67.5-80.4)$ & $67.8(57.2-76.2)$ \\
\hline \multirow[t]{3}{*}{$65+$ years } & 1 yr survival & $94.2(91.6-96.1)$ & $91.8(88.0-94.4)$ & $89.2(83.6-93.0)$ \\
\hline & 3 yr survival & $89.0(85.1-92.0)$ & $84.5(78.9-88.7)$ & $80.0(71.7-86.0)$ \\
\hline & 5 yr survival & $82.8(77.2-87.2)$ & $76.1(68.3-82.2)$ & $69.5(58.5-78.2)$ \\
\hline
\end{tabular}




\begin{tabular}{|c|c|c|c|c|}
\hline \multirow[b]{3}{*}{ Age (years) } & & \multicolumn{3}{|c|}{$\begin{array}{l}\text { Diabetic } \\
\text { Deceased donor } \\
\text { Kidney transplantation } 48 \text { months after initiation of dialysis }\end{array}$} \\
\hline & & \multicolumn{3}{|c|}{$\begin{array}{l}\text { Patient survival } \\
\text { (Expressed as \% survival with confidence intervals in brackets) }\end{array}$} \\
\hline & & Charlson score 2 & Charlson score $3-5$ & Charlson score $\geq 6$ \\
\hline \multirow[t]{3}{*}{$15-24$} & $1 \mathrm{yr}$ survival & $98.0(95.0-99.2)$ & $97.1(92.9-98.8)$ & $96.2(90.7-98.4)$ \\
\hline & 3 yr survival & $95.6(91.4-97.8)$ & $93.7(88.1-96.8)$ & $91.8(84.4-95.7)$ \\
\hline & 5 yr survival & $92.1(86.1-95.6)$ & $88.7(81.1-93.5)$ & $85.6(75.5-91.6)$ \\
\hline \multirow[t]{3}{*}{$25-29$} & $1 \mathrm{yr}$ survival & $96.7(93.6-98.3)$ & $95.3(91.1-97.5)$ & $93.8(88.3-96.7)$ \\
\hline & 3 yr survival & $95.6(92.0-97.6)$ & $93.7(89.0-96.4)$ & $91.7(85.8-95.3)$ \\
\hline & 5 yr survival & $91.1(85.3-94.7)$ & $87.4(80.1-92.1)$ & $83.5(74.3-89.7)$ \\
\hline \multirow[t]{3}{*}{$30-34$} & 1 yr survival & $97.0(94.6-98.3)$ & $95.7(92.5-97.5)$ & $94.3(90.1-96.7)$ \\
\hline & 3 yr survival & $94.6(91.3-96.7)$ & $92.3(88.1-95.1)$ & $89.9(84.5-93.6)$ \\
\hline & 5 yr survival & $91.7(87.1-94.7)$ & $88.2(82.7-92.1)$ & $84.7(77.6-89.7)$ \\
\hline \multirow[t]{3}{*}{$35-39$} & 1 yr survival & $95.9(93.2-97.5)$ & $94.1(90.8-96.3)$ & $92.3(87.9-95.1)$ \\
\hline & 3 yr survival & $91.2(86.8-94.2)$ & $87.5(82.4-91.3)$ & $83.8(77.2-88.6)$ \\
\hline & 5 yr survival & $85.6(79.2-90.2)$ & $79.8(72.7-85.3)$ & $74.1(65.3-81.0)$ \\
\hline \multirow[t]{3}{*}{$40-44$} & $1 \mathrm{yr}$ survival & $95.4(92.6-97.1)$ & $93.4(90.0-95.7)$ & $91.3(86.9-94.3)$ \\
\hline & 3 yr survival & $91.6(87.5-94.4)$ & $88.1(83.3-91.6)$ & $84.5(78.5-89.0)$ \\
\hline & 5 yr survival & $84.6(77.9-89.4)$ & $78.4(71.1-84.1)$ & $72.4(63.6-79.4)$ \\
\hline \multirow[t]{3}{*}{$45-49$} & $1 \mathrm{yr}$ survival & $95.1(92.1-97.0)$ & $93.0(89.3-95.5)$ & $90.8(86.0-94.0)$ \\
\hline & 3 yr survival & $91.2(86.7-94.2)$ & $87.5(82.3-91.3)$ & $83.7(77.1-88.6)$ \\
\hline & 5 yr survival & $85.6(79.0-90.3)$ & $79.9(72.4-85.5)$ & $74.2(65.1-81.2)$ \\
\hline \multirow[t]{3}{*}{$50-54$} & $1 \mathrm{yr}$ survival & $91.7(87.6-94.4)$ & $88.2(83.5-91.6)$ & $84.6(78.6-89.0)$ \\
\hline & 3 yr survival & $86.5(80.9-90.7)$ & $81.2(74.9-86.0)$ & $75.8(68.1-81.8)$ \\
\hline & 5 yr survival & $80.9(73.3-86.6)$ & $73.6(65.6-80.0)$ & $66.5(57.1-74.3)$ \\
\hline \multirow[t]{3}{*}{$55-59$} & 1 yr survival & $90.4(85.6-93.7)$ & $86.4(80.9-90.4)$ & $82.4(75.6-87.4)$ \\
\hline & 3 yr survival & $83.4(76.4-88.5)$ & $76.9(69.4-82.8)$ & $70.6(61.7-77.7)$ \\
\hline & 5 yr survival & $73.7(63.8-81.3)$ & $64.3(54.5-72.5)$ & $55.6(44.8-65.0)$ \\
\hline \multirow[t]{3}{*}{$60-64$} & $1 \mathrm{yr}$ survival & $88.6(82.9-92.4)$ & $83.9(77.5-88.6)$ & $79.1(71.3-85.1)$ \\
\hline & 3 yr survival & $76.5(67.4-83.4)$ & $67.9(58.7-75.5)$ & $59.7(49.4-68.6)$ \\
\hline & 5 yr survival & $65.8(54.1-75.2)$ & $54.5(43.6-64.2)$ & $44.6(33.3-55.3)$ \\
\hline \multirow[t]{3}{*}{$65+$ years } & $1 \mathrm{yr}$ survival & $88.5(82.2-92.6)$ & $83.7(76.5-88.9)$ & $79.0(70.1-85.5)$ \\
\hline & 3 yr survival & $78.6(69.3-85.4)$ & $70.6(60.8-78.4)$ & $62.9(51.8-72.2)$ \\
\hline & 5 yr survival & $67.7(55.4-77.2)$ & $56.8(44.9-67.1)$ & $47.1(34.7-58.6)$ \\
\hline
\end{tabular}


Table 6 of (6)

\begin{tabular}{|c|c|c|c|c|}
\hline \multirow[b]{3}{*}{ Age (years) } & & \multicolumn{3}{|c|}{$\begin{array}{l}\text { Non-diabetic } \\
\text { Deceased donor } \\
\text { Kidney transplantation } 48 \text { months after initiation of dialysis }\end{array}$} \\
\hline & & \multicolumn{3}{|c|}{$\begin{array}{l}\text { Patient survival } \\
\text { (Expressed as \% survival with confidence intervals in brackets) }\end{array}$} \\
\hline & & Charlson score 2 & Charlson score $3-5$ & Charlson score $\geq 6$ \\
\hline \multirow[t]{3}{*}{$15-24$} & 1 yr survival & $98.7(96.9-99.5)$ & $98.2(95.5-99.2)$ & $97.6(93.9-99.0)$ \\
\hline & 3 yr survival & $97.2(94.8-98.5)$ & $96.0(92.4-97.5)$ & $94.7(89.6-97.4)$ \\
\hline & 5 yr survival & $95.0(91.5-97.0)$ & $92.8(87.7-95.8)$ & $90.5(83.3-94.7)$ \\
\hline \multirow[t]{3}{*}{$25-29$} & 1 yr survival & $97.9(96.1-98.9)$ & $97.0(94.3-98.4)$ & $96.1(92.2-98.0)$ \\
\hline & 3 yr survival & $97.2(95.1-98.4)$ & $96.0(92.9-97.8)$ & $94.7(90.3-97.1)$ \\
\hline & 5 yr survival & $94.3(91.0-96.4)$ & $91.9(86.9-95.0)$ & $89.3(82.2-93.7)$ \\
\hline \multirow[t]{3}{*}{$30-34$} & 1 yr survival & $98.1(96.7-98.9)$ & $97.2(95.2-98.4)$ & $96.4(93.4-98.0)$ \\
\hline & 3 yr survival & $96.6(94.7-97.8)$ & $95.1(92.3-96.9)$ & $93.6(89.4-96.1)$ \\
\hline & 5 yr survival & $94.7(92.1-96.5)$ & $92.4(88.6-95.0)$ & $90.0(84.4-93.8)$ \\
\hline \multirow[t]{3}{*}{$35-39$} & 1 yr survival & $97.4(95.9-98.4)$ & $96.3(94.1-97.7)$ & $95.1(91.8-97.1)$ \\
\hline & 3 yr survival & $94.3(92.0-96.1)$ & $92.0(88.4-94.5)$ & $89.5(84.1-93.1)$ \\
\hline & 5 yr survival & $90.7(87.2-93.3)$ & $86.8(81.6-90.6)$ & $82.9(75.1-88.3)$ \\
\hline \multirow[t]{3}{*}{$40-44$} & 1 yr survival & $97.1(95.6-98.1)$ & $95.8(93.6-97.3)$ & $94.5(91.1-96.6)$ \\
\hline & 3 yr survival & $94.7(92.5-96.2)$ & $92.4(89.1-94.7)$ & $90.0(85.1-93.3)$ \\
\hline & 5 yr survival & $90.0(86.5-92.7)$ & $85.9(80.7-89.7)$ & $81.6(73.9-87.3)$ \\
\hline \multirow[t]{3}{*}{$45-49$} & 1 yr survival & $96.9(95.3-98.0)$ & $95.6(93.2-97.1)$ & $94.1(90.6-96.4)$ \\
\hline & 3 yr survival & $94.4(92.0-96.1)$ & $92.0(88.5-94.4)$ & $89.5(84.2-93.0)$ \\
\hline & 5 yr survival & $90.7(87.2-93.3)$ & $86.9(81.7-90.6)$ & $82.9(75.2-88.3)$ \\
\hline \multirow[t]{3}{*}{$50-54$} & 1 yr survival & $94.7(92.6-96.2)$ & $92.4(89.3-94.6)$ & $90.0(85.2-93.3)$ \\
\hline & 3 yr survival & $91.4(88.5-93.5)$ & $87.7(83.4-91.0)$ & $84.0(77.4-88.8)$ \\
\hline & 5 yr survival & $87.6(83.6-90.6)$ & $82.5(76.8-86.9)$ & $77.4(68.8-84.0)$ \\
\hline \multirow[t]{3}{*}{$55-59$} & 1 yr survival & $93.9(91.4-95.7)$ & $91.2(87.6-93.8)$ & $88.5(83.1-92.2)$ \\
\hline & 3 yr survival & $89.3(85.6-92.0)$ & $84.8(79.7-88.8)$ & $80.3(72.6-86.1)$ \\
\hline & 5 yr survival & $82.6(77.3-86.7)$ & $75.8(68.5-81.6)$ & $69.2(58.7-77.5)$ \\
\hline \multirow[t]{3}{*}{$60-64$} & 1 yr survival & $92.7(89.3-94.9)$ & $89.5(85.3-92.6)$ & $86.3(80.1-90.8)$ \\
\hline & 3 yr survival & $84.6(79.9-88.2)$ & $78.4(71.9-83.6)$ & $72.4(62.7-79.9)$ \\
\hline & 5 yr survival & $78.3(71.4-83.7)$ & $68.4(60.0-75.4)$ & $60.3(48.3-70.3)$ \\
\hline \multirow[t]{3}{*}{$65+$ years } & 1 yr survival & $92.6(89.3-94.9)$ & $89.4(84.7-92.8)$ & $86.2(79.3-90.9)$ \\
\hline & 3 yr survival & $86.0(81.1-89.7)$ & $80.4(73.6-85.6)$ & $74.8(65.0-82.2)$ \\
\hline & 5 yr survival & $78.3(71.4-83.7)$ & $70.1(61.0-77.5)$ & $62.4(49.9-72.6)$ \\
\hline
\end{tabular}

